Vol. 5, No. 1, 2019

Khrystyna Kramarchuk, Olga Chelombitko

\title{
SIMILARITY OF GRAMMARS OF ARCHITECTURAL SPACE IN CANONICAL ICONS AND THE ARCHITECTURE OF DECONSTRUCTIVISM
}

\author{
Lviv Polytechnic National University \\ 12, S. Bandery Str., Lviv, 79013, Ukraine \\ khrystyna.gelytovych@gmail.com,vio200574@gmail.com
}

Received: 19.02.2019/Revised: 12.06.2019/Accepted: 18.07.2019

(C) Kramarchuk K., Chelombitko O., 2019

\begin{abstract}
The analogies in the grammar of architectural space in an icon and the architecture of deconstructivism have been revealed, the factors of influence on the formation of the grammar of the architecture of deconstructivism and architectural space in an icon have been listed, as well as the comparison of the grammar of the architecture of deconstructivism and architectural space in an icon has been made.
\end{abstract}

Key words: perceptual perspective, reverse perspective, architectural space in an icon, the architecture of deconstructivism.

\section{Introduction}

1.1. Problem stating: The evolutionary scientific tendency to knowledge gaining and the psychological peculiarity of human perception through associative-figurative interaction of objects led to the discovery of common rules in construction of the architecture of deconstructivism and architectural space of an icon. A new look at the well-known things generates new knowledge. Destructive fragments of the architecture in icons, which are built according to the laws of perceptual perspective, generate associations with the architecture of deconstructivism and, as a result, encourage deeper understanding of the associative relations between them.

1.2. Article objectives: 1 ) To show the connection of the perceptual perspective in an icon and the architecture of deconstructivism with non-Euclidean space, with n-dimensional space; 2) To reveal the ideological (conceptual) factors which influence the development of the grammar of the architecture of deconstructivism and architectural space in an icon; 3) To identify general rules of the grammar of the architecture of deconstructivism and create the image system in an icon with the help of architectural forms (so-called "chamber writing").

1.3. The analysis of recent studies and publications has shown that the theory of perceptual perspective in an icon was revealed by B.V. Rauschenbach [1975], reverse perspective - by P. Florensky [2008]. Poetics and in particular the grammar ${ }^{1}$ of architecture of deconstructivism are disclosed by C. Jencks [1985], I. A. Dobritsyna [2004], which is based on the concepts of such philosophers as J. Derrida, M. Foucault and semiotician R. Barthes, as well as on the theoretical architects of deconstructivism Peter Eisenman, Bernard Tschumi, Remment Koolhaas, Daniel Libeskind and Zaha Hadid. The author does not know any publication, which reveals the idea of comparing and collation of the construction of architectural space with an icon and the architecture of deconstructivism.

\footnotetext{
${ }^{1}$ Grammar includes morphology, syntax and morphogenesis regularity (form creation).
} 


\section{Basic theoretical section}

\subsection{The system of perceptual perspective in the light of spatial theories.}

The formation of perceptual space (the process of perception of space) occurs according to the following scheme of objective space $\rightarrow$ image on the retina $\rightarrow$ perceptual space (compressed information is needed in this context) [Rauschenbach, 1975, p. 129, 153]. The perceptual perspective is something between the spatial and plane images of the object. B.V. Rauschenbach [1975, p. 154] proves that the properties of the perceptual perspective due to the psychology of human perception at small distances $(12 \mathrm{~m}-19 \mathrm{~m}-$ the space of the immediate environment of a person) can be formally described as the properties of Riemann space of a negative curvature (1851), that is the properties of Lobachevsky space (1826), which at the same time are the properties of a reverse perspective. The perceptual perspective includes a reverse perspective. According to P. Florensky [2008, p. 62] a reverse perspective 1) does not believe in three-dimensionality, homogeneity of the Euclidean space; 2) excludes a special single point of ascension, while all places of space are equal; 3) uses the mechanisms of a binocular vision, not a monocular one as a linear perspective; 4) does not think that the world is immovable and unchanged, shows the subject from different points of view; 5) includes all psycho-physiological processes of the act of sight, which are accompanied by memories, spiritual efforts and knowledge. All this indicates the non-Euclidean nature of the perceptual space that surrounds us. Characteristics of the Euclidean and non-Euclidean spaces are presented in Table 1.

Table 1

The system of perceptual perspective and non-Euclidean space

\begin{tabular}{|l|l|l|}
\hline \multicolumn{2}{|c|}{ Euclidean space } & \multicolumn{1}{|c|}{ Non-Euclidean space (by Lobachevsky and Riemann ) } \\
\hline $\begin{array}{l}\text { Euclidean geometry - two straight } \\
\text { lines perpendicular to the third one } \\
\text { are parallel }\end{array}$ & $\begin{array}{l}\text { Hyperbolic geometry - two straight } \\
\text { lines, perpendicular to the third one } \\
\text { "run away" from each other, in case } \\
\text { of moving from the points of } \\
\text { intersection with the common } \\
\text { perpendicular }\end{array}$ & $\begin{array}{l}\text { Spherical geometry - two straight } \\
\text { lines, pendicular to the third one, } \\
\text { and eventually intersect }\end{array}$ \\
\hline $\begin{array}{l}\text { Zero curvature of the space }- \\
\text { constructs the axonometry of the } \\
\text { middle plan }\end{array}$ & $\begin{array}{l}\text { Negative curvature of the space }- \\
\text { forms the reverse perspective of the } \\
\text { foreground }\end{array}$ & $\begin{array}{l}\text { Positive curvature of space - forms a } \\
\text { linear and curved perspective of the } \\
\text { middle ground and the background }\end{array}$ \\
\hline
\end{tabular}

The curvilinear perspective (negative and positive curvature) was used in icons depicting thrones, beds and other constructions. V. N. Prokofiev [Rauschenbach, 1975, p. 180] points out that the masters of the Northern Renaissance (Bosch, Bruegel) noticed the effect of the concavity / prominence of the horizon line, the cup-like appearance of the earth's space, while the space of the artist P. Sezanne is a spheroidal-dynamic field (by Lilian Gerry). B. V. Rauschenbach [1975, p. 162] indicates that the perceptual space is much more complicated and the closest analogy to the perceptual space is a four-dimensional model of Einstein's spacetime, which has a variable curvature caused by the placement of masses in space. Thus, the energy of the gravitational field (generated by substance) is capable to deform space-time so that the lines in space and time have the properties of "curved" lines (Pic. 1). If we talk about the analogy between Einstein's space and the perceptual space, a priori information of the observer (the constant of the form and value) plays the role of mass in Einstein's space: just as the increase in the quantity of mass in some area of the physical space causes an increase in the curvature of space, as well as an increase in a priori information about objects of a 
certain area of perceptual space causes an increase in its deformation (use in the image of a spatial object on the plane of the method of a moving point of view in all directions).

The morphology of the perceptual space as a result of the performance of the mechanism of the constant value becomes the Riemann space of an alternating curvilinear (negative, positive) reflected in the image of the road (Pic. 2).

In the basis of the futuristic, cubist, surrealistic, suprematic painting, sculpture, architecture of deconstructivism and nonlinear architecture lays the expression of motion in two forms: "penetration inside" as a method of multiplying and "simultaneity" (so-called illusion of a one-way movement) - a long period of time in one moment to comprehend the space which is depicted not from one privileged point of view. In this case, the perceptual perspective is hyperbolized, which is built on the mechanism of constancy of the form. Analytical cubism by avoiding colours simplifies natural forms to geometric, analyzes two or more object views simultaneously (side and top projection of dishes, a table), presenting them together in the same way as in icons. But still deconstructivism first comes to one's mind while looking at the architectural space in an icon.
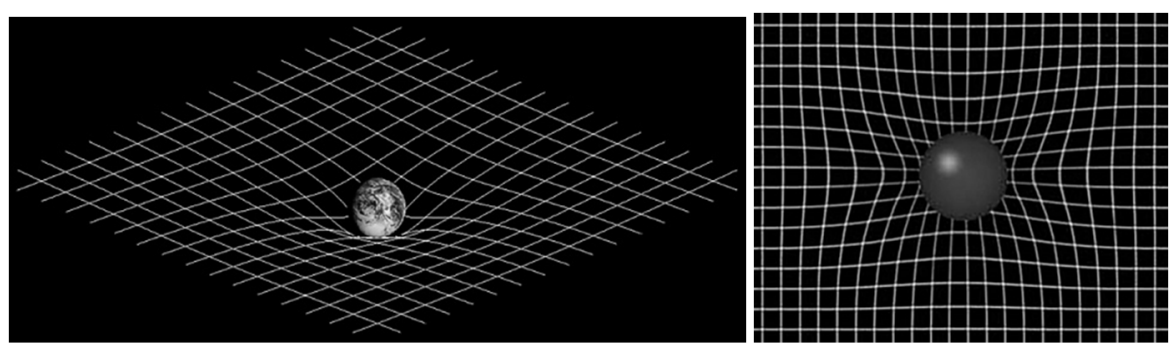

Pic. 1. Einstein's theory about a four-dimensional model of space-time. Image source is http://www.zamandayolculuk.com/html-1/relativityfile.htm

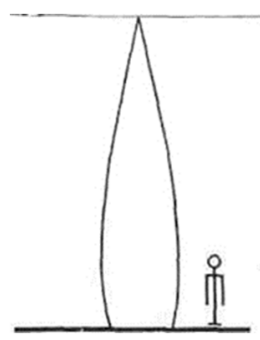

Pic. 2. A picture of the road in a perceptual perspective [Rauschenbach,1975]

\subsection{Grammar of architectural space in an icon.}

The grammar of the space construction with architectural objects (the method of "chamber writing") in an icon developed in the Palaiologan period of Byzantine art (1261-1453.) It is the space with the effect of metaphysics and the interactive ${ }^{2}$ attraction of the viewer into the space of the Universe of other-existence. Thus, an icon looks at us due to its construction in the system of perceptual perspective and in particular the reverse one, where the meeting point of these reverse-spatial constructions is a real person. For Byzantine and Ukrainian icon painting as well as medieval painting, there is a characteristic perceptual perspective. The system of perceptual perspective is characterised by complex differential equations in contrast to the linear one, although it was built by artists intuitively without complex geometric theory while the linear one requires certain knowledge in construction. The perceptual perspective takes into account two factors: 1) optical illusions in perception; 2) real knowledge about the environment. Using the perceptual perspective an icon painter has the possibility to construct the architectural space of an icon (he chooses which parts of the object or the plane to depict in a curved way and in what perspective to depict each architectural object or fragment of the object, for example, isometry, the combination of orthogonal projections, reverse, linear, curved perspectives (Pic. 3a), as well as an architect who works in the style of deconstructivism can compose spaces and planes in different variations. The degree of deformation of the perceptual space depends on a priori information about the objects which are possessed by the observer. The system of perceptual perspective gives an opportunity to an artist to transfer locally correct images taking into account the

${ }^{2}$ Interaction is the ability of the onlooker to act upon an artistic object with the aim of its transformation (I. A. Dobritsyna), involving the onlooker in the process of understanding of a certain information (S. M. Linda, B. S. Cherkes) 
mechanism of magnitude and form constancy, for example, by showing two angles correctly in the object of the parallel-shaped form, and the third one is curved. The sum of angles of a parallelepiped in the perceptual perspective will be $270^{\circ}<\alpha<\beta<\gamma<360^{\circ}$. The mechanism of magnitude constancy redefines the image on the retina in a whole, while the mechanism of form constancy acts only on those elements of the image on the retina, which are well-known objects to the viewer from his life experience (vision plus knowledge).

It should be noted that in the article we compare the perceptual perspective (plane-spatial), which reflected objects form, in our case, they are the architecture in an icon and the real space created by the architecture of deconstructivism. A continuous depiction of a three-dimensional space (for example, $\mathrm{n}=3)$ on a plane $(\mathrm{m}=2)$ is only possible with refusal of unambiguous conformity if $\mathrm{m}<\mathrm{n}$. Similarly, with forms in four-dimensional space, when we change them into three-dimensional one, we obtain a hypersurface $^{3}$ (hypercube - tesseract). The new possibilities of spatial measurements the artists call the fourth dimension $^{4}$, the three-dimensional Euclidean space has changed to the space of the vastness in all directions, and every moment, "the fourth dimension gives the objects a plasticity" (G. Apoliner). Today, the fourth dimension projected into three-dimensional space is understood through the hyper-surfaces. The method of transmitting the four-dimensional space in an icon happens due to the splitting method. As a result the coexisting three-dimensional spaces, for example, in an icon, the objective and mystical spaces (parallel worlds) are shown alternately. Moreover, the transmission of two three-dimensional "layers" of a four-dimensional space is reduced to the transmission of the geometry of the three dimensional space, where the areas (fragments) of these layers "adjoin" with each other, and are not "superposed" upon the other. The mutual penetration of the plans in the space of an icon is created with the method of layering of light, bleached ocher on the colored background and the method of geometric contradictions (Pic. 6, 9). In an icon, a small spatial depth is revealed with the help of a moving point of the view as vertically (different levels of the horizon (the view from the bottom is combined with the view from the top), and horizontally (combining the appearance of the object from three sides), methods of geometric and lightshadow contradictions in perspective constructions, effects of omission in the construction of forms, which allows to complete it in different variations, "transitions / refractions of the frontal plane of the walls in a binary curvature - all this creates the decentralization of the perspective, the complexity of perception and metamorphology of architectural space in an icon (Pic. 3a, Pic. 7).

\subsection{Conceptual principles of the architecture of deconstructivism and architectural space in an icon.}

The philosophical concept of the deconstructivism involves revealing of the hidden content, which is visualized with the help of formal methods of fragmentation, multilayer, fracturing of planes, complex geometry of an architectural image and its aggressive invasion in the urban environment. Theological conception of an icon is a manifestation of supersensible, immortal, invisible world through a system of perceptual perspective as sensual, real and visible one by applying the figurative methods of iconography, besides that an ontological connection is established between the image and the icon.

The main task is to strengthen the ideological and artistic dimensions of an icon and an architectural object of deconstructivism, to create a metaphysical space. But the ideological factors that influence the formation of the grammar of the architecture of deconstructivism and architectural space in an icon are slightly different (Table 2).

\footnotetext{
${ }^{3}$ Hypersurface is a generalization of the concept of the usual surface in a three-dimensional space in case of a multi-dimensional space.

${ }^{4}$ A four-dimensional space (marking: 4D or R4) is a mathematical object that summarizes the properties of a three-dimensional space. It should not be confused with the four-dimensional space-time theory of relativity (the space of Minkowsky). Algebraically, four-dimensional space can be constructed as a set of vectors with four valid coordinates. Geometrically, in the simplest case, the four-dimensional space is considered to be the Euclidean space of four dimensions; in general, it has a non-Euclidean metric, which is varied from point to point. Available at: https://uk.wikipedia.org/wiki
} 
The difference between the ideological factors in the formation of the grammar of the architecture of deconstructivism and the construction of the architectural space in an icon

\begin{tabular}{|l|l|}
\hline \multicolumn{1}{|c|}{$\begin{array}{c}\text { The architecture of deconstructivism } \\
\text { the principles of post-structuralism concepts) }\end{array}$} & \multicolumn{1}{|c|}{ The architectural space in an icon } \\
\hline $\begin{array}{l}\text { The impossibility of a modern man to experience the world } \\
\text { order as harmony and integrity, the transformation of the } \\
\text { ontological connection with the metaphysical }\end{array}$ & $\begin{array}{l}\text { An ontological connection is established between the } \\
\text { image (icon) and its original image (God) and a man }\end{array}$ \\
\hline $\begin{array}{l}\text { The architecture of deconstructivism is an experiment with } \\
\text { reality } \rightarrow \text { creating another reality. The space of the } \\
\text { experiment space with form and meaning. Deconstruction as } \\
\text { a method of analysis }\end{array}$ & $\begin{array}{l}\text { The architectural forms in an icon express the } \\
\text { ontology of reality (the embodiment of the synthesis } \\
\text { of the sensory experience of the form and the spiritual } \\
\text { efforts of recognition, the process of contemplation- } \\
\text { perception, the understanding of Eternity) }\end{array}$ \\
\hline $\begin{array}{l}\text { Violation of the mechanism of form constancy, broken } \\
\text { perfection }\end{array}$ & $\begin{array}{l}\text { Application of the mechanism of form constancy. } \\
\text { Search for perfection. }\end{array}$ \\
\hline $\begin{array}{l}\text { Mechanistic aesthetics of forced de-structuring, aesthetics of } \\
\text { disturbed perfection. Mechanical installation. Doubts about } \\
\text { the values of the structure }\end{array}$ & Aesthetics of visible and spiritual experience \\
\hline $\begin{array}{l}\text { "Open Architecture" - in which the syntactic structures of } \\
\text { the architectural language are freed from connection with } \\
\text { utilitarian needs (functional and semantic), "sign fighting," } \\
\text { the complexity of meaning reading "meaning flicker") }\end{array}$ & $\begin{array}{l}\text { Each form is symbolic and works on the plot, the } \\
\text { event of an icon }\end{array}$ \\
\hline $\begin{array}{l}\text { The emphasis on the new syntax and morphogenesis as } \\
\text { opposed to existing ideas about architecture, the concept of } \\
\text { equivalence of form and space }\end{array}$ & $\begin{array}{l}\text { The emphasis on metamorphology (thorough } \\
\text { uncovering of sensual and spiritual experience of } \\
\text { perception of existing reality, complex syntax of } \\
\text { forms and space) }\end{array}$ \\
\hline
\end{tabular}

\subsection{The principles of grammar of deconstructivism}

As it has been mentioned above, the system of perceptual perspective in an icon consists of separate perspectives of the image of architectural objects and objects of interior: axonometric, linear, curved and inverse (Pic. 3a). Moreover, if the general outline of buildings is approaching axonometry, fragments, details of these buildings are constructed in reverse, linear and curved perspectives, and these perspectives create similarities between architectural forms or interior elements and form the ensemble of the architectural space of an icon. It is the same "romance of scale", which was used in Gothic (latitudinal) and baroque (hyperbolisation) due to the similarity of parts to the whole which created the effect of metaphysical space. By the modern architectural terminology this method is called "staccato" dissolubility that creates a scattered perspective of the image, without a specific point of ascension, simulates the situation of equivalence of elements of the universe which is also typical for the style of deconstructivism. The main manifestos of deconstructivism are 1) deformation of the compositional motives of constructivism; 2) curvilinear architecture. This first concept can already be found during the

5 «Romantic of scale» is a manifestation of the principle of analogy, similarity, the creation of values of similar forms and sizes primarily in architecture. Creating nuances, with the help of which different values in the architectural composition are in harmony with each other. The common "romantic of scale" in Gothic: the same form on the facade was repeated in the interior, altars, choral chairs, relics, so-called miniaturization. In baroque the details increased in size (maximization): cartouches, volutes, balusters, which decorate the buildings. In both cases, the compositions create a certain metaphysical space, as the forms change into one another, there is a decreasing or enlarged reflection.// Dictionary. V. V. Vereshchagin. The Internet source: http://www.veresshagin.ru 
Italian Mannerism of 1525-1620 as a parody of the classics, where constructive elements such as triglyphs and metopes or castle stones, columns are depicted athectonically on purpose (for example, the architect Julio Romano Palazzo del Te in Mantua). The curvilinear architecture of deconstructivism sends us to the baroque plastic arts.
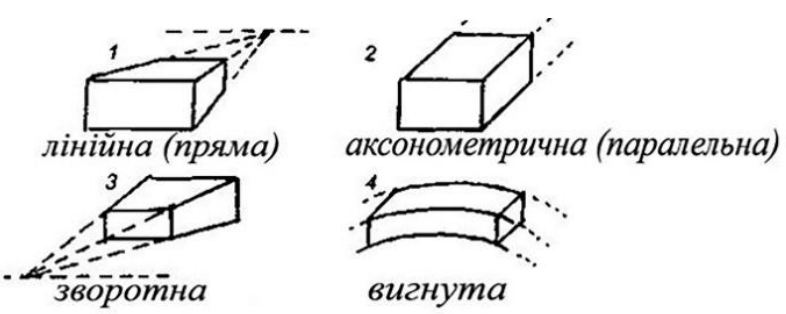

Pic. 3a. Perspectives of the image of architectural objects in an icon as a way of perception of reality: 1) linear (direct);

2) axonometric (parallel); 3) reverse; 4) convex

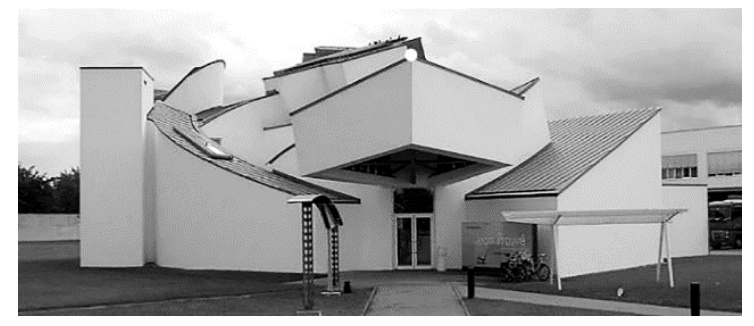

Pic. 3b. A real combination of forms. Vitra Design Museum at Weilly-on-Rhine, Germany, 1990. F. Gary

Deconstructivism is characterized by atectonics, it is not clear how certain structures carry out their bearing function, the feeling of the absence of gravity. The basic principle of deconstructivism is a hidden work of structures. In interiors of the style of deconstructivism, a person gets into the space conditions, which is difficult to assess in its geometry, and which is typical for the virtual world [Zymina, p. 276]. For deconstructivism, the method of induction or juxtaposition is a characteristic one (typing figures one into another or their chaotic imposing one on another), which is built according to the scheme of assembling dismantling - reassembling. Syntax of dismantling: stratification, doubling, cutting, turning and, according to re-assembling, it can be with intended displacements, rearrangements, merging, bias, and other inverse interspersions. The leader of deconstructivism, Bernard Tschumi, also accepts the juxtaposition as a semantic plan: juxtaposition is a chaotic imposing of various cultural meanings, a stick, and a collision of uncertain cultural meanings. Uncertainly, dynamics is a characteristic feature of a new type of space (P. Eisenman) [Dobritsyna, p. 135-158]. A task to create a dynamic new type of space was put forward by the masters of the Italian mannerism, baroque, avant-garde, deconstructivism, and now is put by the masters of the electronic baroque.

\section{Comparison of the architecture of deconstructivism and architectural space in an icon}

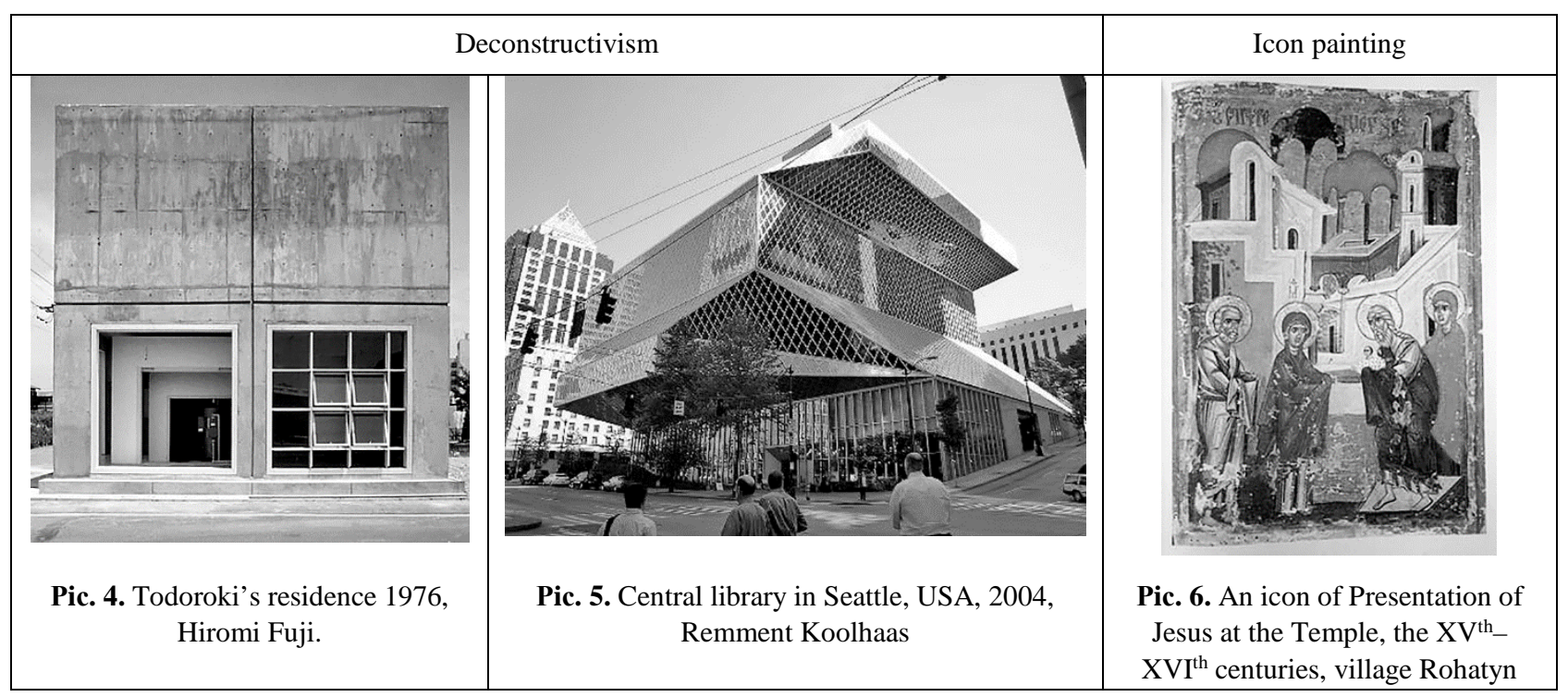




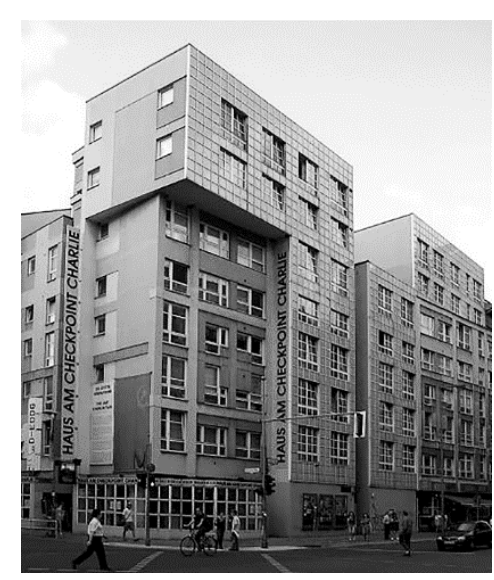

Pic. 7. A building in Berlin, P. Eisenman

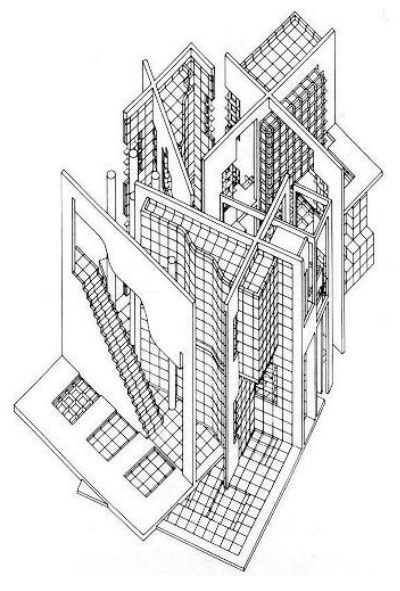

Pic. 8. A building project. Hiromi Fuji T39

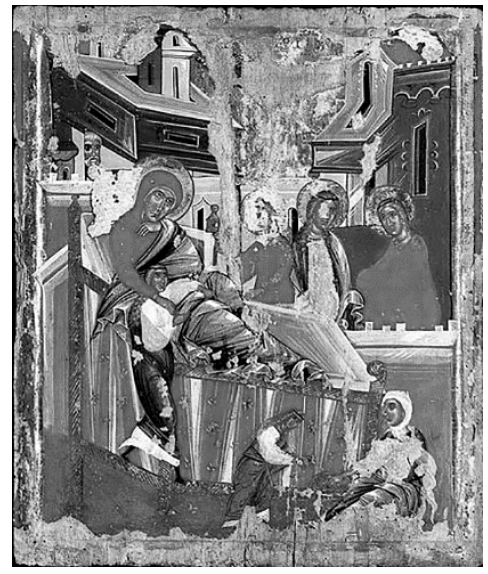

Pic. 9. Blessed Virgin Mary Nativity the XVI ${ }^{\text {th }}$ century, village Rohatyn, St. Demetrius church (now territory of Poland)

\section{Results}

The system of perceptual perspective makes the basis of the grammar of the architectural space in an icon. Comparison of the grammar of the architectural space in an icon and the architecture of deconstructivism, which includes the morphology, syntax and regularities of morphogenesis (form creation) is summarized in Table 4.

\section{Common grammar rules for the construction of architectural space in an icon and the architecture of deconstructivism}

\begin{tabular}{|c|c|}
\hline The architecture of deconstructivism & The architectural space in an icon \\
\hline 1 & 2 \\
\hline \multicolumn{2}{|c|}{ 1. Regularities of morphogenesis } \\
\hline $\begin{array}{l}\text { 1.1. An image of a four-dimensional or } \mathrm{n} \text {-dimensional } \\
\text { space in a three-dimensional space }(\mathrm{m})\end{array}$ & $\begin{array}{l}\text { 1.1. An image of a three-dimensional space in a two- } \\
\text { dimensional space }\end{array}$ \\
\hline \multicolumn{2}{|c|}{ 1.2. $\mathrm{m}<\mathrm{n}$} \\
\hline $\begin{array}{l}\text { 1.3. Increased postmodernism sensuality in perception } \\
\text { (intuition, metaphor) is caused by the unstable position } \\
\text { of a man in the world }\end{array}$ & $\begin{array}{l}\text { 1.3. Perceptual perspective }- \text { semantic (sensory- } \\
\text { perceptual) and semantic knowledge about reality }\end{array}$ \\
\hline $\begin{array}{l}\text { 1.4. Anamorphic distorted projection of reality. Feeling } \\
\text { the impossibility of space }\end{array}$ & $\begin{array}{l}\text { 1.4. Geometric contradictions - a conscious distortion of } \\
\text { the form of the depicted subject (Pic. } 6 \text { ) }\end{array}$ \\
\hline $\begin{array}{l}\text { 1.5. The effect of the designing process, combinatorics, } \\
\text { the state of uncertainty. Imperfection - as a designing } \\
\text { option }\end{array}$ & $\begin{array}{l}\text { 1.5. Method of understatement (it is given an opportunity } \\
\text { to perceive an object as in axonometry as in the reverse or } \\
\text { linear perspective) }\end{array}$ \\
\hline \multicolumn{2}{|c|}{ 2. Morphology and syntax } \\
\hline $\begin{array}{l}\text { 2.1. Deconstruction is a distortion of "architectural } \\
\text { logic and the laws of tectonics". The degree of the } \\
\text { distortion depends on imagination - the process of play } \\
\text { (artistic trails: alogism, paradox) }\end{array}$ & $\begin{array}{l}\text { 2.1. The degree of a space deformation depends on a priori } \\
\text { information which a person has about the depicted subject }\end{array}$ \\
\hline
\end{tabular}


Continuation of table 4

\begin{tabular}{|l|l|}
\hline \multicolumn{1}{|c|}{ 2.2. "Irregular" form, bright contrasting colours } \\
\hline \multicolumn{2}{|c|}{ 2.3. Method of juxtaposition, superposition (Pic. 4, 9) } \\
\hline \multicolumn{2}{|c|}{ 2.4. The labyrinth reality, the perception of a strained space (Pic. 6, 8, 9) } \\
\hline \multicolumn{2}{|c|}{ 2.5. Multilayer space, scale changing ("romance of scale"), a dialogue between a part and whole (Pic. 4) } \\
\hline $\begin{array}{l}\text { 2.6. Perspective decentralization } \\
\text { Condition of uncertainty (Pic. 3b) }\end{array}$ & $\begin{array}{l}\text { 2.6. Scattered perspective, multicentre perspective. The } \\
\text { equivalence of all elements of the structure, each element } \\
\text { has its own horizon. } \\
\text { Condition of uncertainty }\end{array}$ \\
\hline $\begin{array}{l}\text { 2.7. Fragmentation (evil, dimensional turns). } \\
\text { Disclosure of shallow spaces, aspect composition }\end{array}$ & $\begin{array}{l}\text { 2.7. Fragmentation (a combination of linear, curved, } \\
\text { parallel, reverse perspective of separate objects) }\end{array}$ \\
\hline $\begin{array}{l}\text { 2.8. Angular capacities (main angles of perception on } \\
\text { the corner), Pic. 5, 7 }\end{array}$ & $\begin{array}{l}\text { 2.8. Depiction of architectural objects from the corner } \\
\text { (revealing the depth and completeness of knowledge about } \\
\text { the object), Pic. 6, 9 }\end{array}$ \\
\hline $\begin{array}{l}\text { 2.9. Language of confrontation (dynamics-statics, } \\
\text { symmetry-asymmetry) }\end{array}$ & $\begin{array}{l}\text { 2.9. Presentation of the form from different points of view } \\
\text { (combination of the top and bottom views, and of } \\
\text { axonometry and orthogonal projections, combination of } \\
\text { orthogonal projections, the method of simultaneity }\end{array}$ \\
\hline
\end{tabular}

\section{Conclusions}

The perceptual perspective in an icon is subordinated to a subjective factor (it allows to freely apply knowledge about the object) as well as in deconstructivism, where the mechanical assembling of parts is generated by the aesthetics and semantics of subjectivity. The distortion of the architectural space in an icon is caused by the psychology of the perception of several plans by a person, namely, the nearest plane is seen according to the laws of the inverse perspective (negative curvature). The middle plan is spherical, so-called convex perspective, and the background is the linear perspective (positive curvature). The maximum artistic expression, which the grammar of space building in deconstructivism works on, causes the game of contents: the attempt to find ambivalence, the recognition of competitive interpretations, while the grammar of the architectural space in an icon embodies the spiritual experience in the cognition of the metaphysical world.

Similar methods of constructing of the architectural space in an icon and the architecture of deconstructivism are: 1) scattered, decentralized perspective of an image which leads to the fragmentation and disclosure of shallow spaces; 2) depiction of the form from different points of view; 3 ) the methods of geometric contradictions (icon) and unreality of forms (deconstructivism); 4) the method of juxtaposition, superposition and disperse multilayer space; 5) the method of understatement (the possibility of the form perception as in axonometry as in reverse or linear perspective).

The similarity of the purpose of the space constructing in an icon and in deconstructivism which is to reveal the hidden meanings, the essence, to achieve the quality of metaphysical forms. The difference is in the interpretation of reality. Thus, the architectural forms in an icon express the ontology of reality (the embodiment of the synthesis of sensory experience of the physiological space of a man and spiritual experience in contemplation-cognition), while the architecture of deconstructivism is an experiment with reality (distortion), mechanistic aesthetics of violent destruction, changed perfection, which is caused by increased sensitivity to the problems in relationship "man - the modern civilized world". An icon focuses on metamorphology (comprehensive disclosure of sensual and spiritual experiences of perception of existing reality, complex syntax 
of forms and space), when deconstructivism focuses on the new morphogenesis and the concept of forms and space equivalence.

\title{
References
}

[1] Dobritsyna, I., 2004. Ot postmodernizma - k nelinejnoj arkhitekture: arkhitektura v kontekste sovremennoj filosofii i nauke. Moskwa: Progress-Tradicyja.

[2] Florensky, P., 2008. Imena: Sochinenyja. Moskwa: Eksmo.

[3] Jenks, C., 1985. Jazyk arkhitektury postmodernizma. Translated from English by A. V. Riabushyn, M. V. Uvarova. Moskwa: Strojizdat.

[4] Rauschenbach, B., 1975. Prostranstvennyje postrojenija v drevnerusskoj zhivopisi. Moskwa: Nauka.

[5] Zymina, S., 2018. Styli interjeru. Kyiv: Dovira.

\section{Христина Крамарчук, Ольга Челомбітько}

\section{ПОДІБНІСТЬ ГРАМАТИКИ АРХІТЕКТУРНОГО ПРОСТОРУ В КАНОНІЧНИХ ІКОНАХ ТА АРХІТЕКТУРИ ДЕКОНСТРУКТИВІЗМУ}

\begin{abstract}
Анотація. У статті розглянуто граматику архітектурного простору в іконі (зображення тривимірного простору у двовимірному) та граматику архітектури деконструктивізму (зображення п-вимірного простору у тривимірному), де за спільну основу взято закономірність морфогенезу: зображення у меншому т-вимірному просторі, більшого п-вимірного простору. Розкривається граматика базової периептивної перспективи в іконі. Перцептивна перспектива підпорядкована суб'єктивному чиннику (дає змогу вільно застосовувати знання про об'єкт) так як $і$ в деконструктивізмі, де механічний монтаж частин породжений естетикою і семантикою суб'єктивізму. Викривленість архітектурного простору в іконі зумовлена психологією сприйняття плановості людиною, а саме, ближні простори людина бачить за законами зворотної перспективи (від'ємна кривина). Середній план є сферичним, так звана опукла перспектива, а задній план - лінійна перспектива (додатна кривина). Максимальна художня виразність, на яку працює граматика побудови простору в деконструктивізмі породжує гру змістами: намагання знайти амбівалентність, визнання конкурентних інтерпретацій, тим часом як граматика архітектурного простору в іконі втілює духовний досвід у пізнанні метафізичного світу.

Визначено, щуо однаковими методами побудови архітектурного простору ікони і архітектури деконструктивізму є: 1) розсіяна, децентралізована перспектива зображення, звідси фрагментарність і розкриття неглибоких просторів; 2) подача форми з різних поглядів; 3) прийняття геометричних протиріч (ікона) і нереальність форм (деконструктивізм); 4) прийняття джакстапозиції, суперпозииї і дисперсного багатошарового простору; 5) прийняття недомовленості (можливість сприйняття форми і в аксонометрії, й в зворотній або лінійній перспективі).

Виявлено подібність мети побудови простору в іконі, як і в деконструктивізмі - розкрити приховані змісти, сутності, досягнути якості метафізичності форм. Відмінність у трактуванні реальності: архітектурні форми в іконі виражають онтологію реальності (втілення синтезу чуттєвого досвіду фізіологічного простору людини і духовного досвіду у спогляданні-пізнанні), водночас архітектура деконструктивізму ие експеримент з реальністю (викривлення), механістична естетика насильної руйнаиії, порушеної досконалості, спричинена підвищенною чуттєвістю до проблем у відноменні «людина - сучасний иивілізаційний світ». Ікона акиентує увагу на метаморфології (всебічне розкриття чуттевого $i$ духовного досвіду сприйняття існуючої реальності, складний синтаксис форм $i$ простору), а деконструктивізм - на новому морфогенезі й концепиії рівнозначності форми і простору.
\end{abstract}

Ключові слова: перцептивна перспектива, зворотна перспектива, архітектурний простір в іконі, архітектура деконструктивізму. 